\title{
Sustainable Development for Public Administration: Effective Management Administrative System of the 21st Century Public Administration
}

\author{
Caroline Covell, PhD, MPA, BComm, BA. \\ Walden University Public Policy and Administration
}

Email: carol59@xplornet.com

Received: March 09, 2016 Accepted: March 26, 2016 Published: May 13, 2016

doi:10.5296/jpag.v6i2.9368 URL: http://dx.doi.org/10.5296/jpag.v6i2.9368

\begin{abstract}
Reinventing the government was big in the early 1980s; post media presentation that echoed how inefficient the government has been. Ever since, the government went through different reorganization processes through the application of different modern management theories, endorsed by the politicians, such as the Hawthorne theory, the Gantt Theory, Mintzberg Management Theory, Theory $\mathrm{X}$ and $\mathrm{Y}$, and the Agency Theory - all promise efficient government. They were implemented as a trial and error - one fails try another. This management system separates the top management and bottom level management, known also as an operational management. This system was introduced in a fanfare but it represents a hollow system. Overtime, all these modern management theories, which Ghoshal argued as bad theories, have destroyed good management practice of a public institution. Its management and administrative system are broken, the institution becomes very dysfunctional, and it causes a badly divided government. This damaged system makes it easy for theft, fraud, corruption, bribery, grafts, sabotage, espionage, and all kinds of illegal practices. At the same time, the change causes the used to be a professional public institution to become an amateur corporation that is individually managed, personally ruled, and undemocratic governance. Leadership does not exist in this system, neither does the middle level management, and it also suffers from severe democratic deficits. This paper discusses the theoretical foundation of the bureaucracy and its analysis, and using holistic and phenomenological approaches, this theory can be applied in the management administrative system of government, and this dysfunctionality and the broken system can be remedied practically.
\end{abstract}

Keywords: Sustainable development, Administration, Bureaucracy 


\section{Introduction}

Reinventing the government was big in the early 1980s; post media presentation that echoed how inefficient the government has been. Ever since, the government went through different reorganization processes through the application of different modern management theories, endorsed by the politicians, such as the Hawthorne theory, the Gantt Theory, Mintzberg Management Theory, Theory X and Y, and the Agency Theory - all promise efficient government. All promise efficient government. They were implemented as a trial and error one fails try another. This management system separates the top or APEX management and bottom level management, known also as an operational management. This system was introduced in a fanfare but it represents a hollow system. Overtime, all these modern management theories, which Ghoshal argued as bad theories, have destroyed good management practice of a public institution. Its management and administrative system are broken, the institution becomes very dysfunctional.

The leaders come directly from the private sector as elected and appointed leaders and they declare that they are reformers who bring change and will make the government efficient. Once in the bureaucracy, they lay off the public servants and replace them with their "birds of the same feathers," who are political exempt staffs, whose sole purpose of working in the bureaucracy is to serve their political masters (Brodie, 2012) - elected and appointed. As "birds of the same feathers," they shield their masters from their poor or lack of performance and even act as their gatekeepers. They keep the citizens away from their masters or that their masters should not be bothered by the citizens' problems. They are also known as political exempt staffs and they work in the bureaucracy without going through the rigorous screening and training the public servants have to go through. In fact, the rules and laws that bind the public servants are not applicable to them. That is why they are called "political exempt staffs." Marley (1997) called them the Pharaoh's slaves and they will die together with their masters. These leaders come and go or they mobile from one bureaucratic organization to another within a short-term. Their average term of service is between six months and twenty-four months. Hence, the turnover rate among the public leaders and the political exempt staffs is very high. None of the leaders is ever given proper training or has ever gone through a developmental process and transformational process and they never read any incoming and outgoing information. They form their own team at the top through networking.

Besides the political exempt staffs and the public servants, there are part-time, casual, seasonal, and temporary personnel who are sent to work in the government by the staffing agencies. They are people who have similar background and pooled together to perform multiple tasks (McShane, 1992). There are also volunteer who come to work in the government as leaders, and once the leadership position is opened, they apply for the position. None of these individuals and the political exempt staffs are given training about the management and administration of the bureaucracy. Education is considered insignificant as long as the persons are able to "learn by the seat of their pants" (Anderson, Hilderman, \& Loat, 2010) or just willing to "learn on the job." As a result, these people do things similar to their habits from the environment they are experienced in. 
Ironically, for every change they bring the more dysfunction the institution becomesand the more damaged the management and the administrative system of the bureaucracy has been. The used to be a professional public institution has now become an amateur corporation that is individually managed, personally ruled, and undemocratic governance. Despite the glamour of the promise of the reinventing the government, the change has proven a failure effort.

Under this dual function management system, the top management has little to do with the management and operation of the organization. The leaders, argued Killian (2005/2007), form their own team at the top through networking and joining "pop and soda" clubs. According to Killian, these leaders do not consider themselves as part of the team in the organization and would rather assign tasks to people they have personal connection outside the organization. At the same time, they allow people at the bottom level, who have the same background and similar knowledge to do multiple tasks (McShane, 1992), including the authority to make decisions on their behalf.

Ironically, the dual system of bureaucratic management has caused the knowledge or mental workers to become an endangered species in the bureaucracy. Most people at the front line come from the political parties, without knowledge about the government and without special training about the government organization and its management and administrative system, and they are poorly educated or lack education. With knowledge deficits and without special training about the bureaucratic management and administrative system, these frontline staffs and the political exempt staffs, contribute to the dysfunctional system of management while the organization operates as a hollow system or without the backbone. In terms of leadership, the leaders represent an army of talkers rather than doers. They represent people who "expose the hollowness of the leaders today" (Ghosh, 2012). They talk big but do very little (Clawson, 2003) and represent idlers (Rev. Beecher, 1885), which are the greatest curse of human capital.

The dysfunctionality multiplies because the change they bring is an outside inward and this change is always a failure effort. Towne (in Shafritz, Ott, \& Jung, 2005) stated, when there is a dysfunctionality in an organization; ask a person who is specially trained in the field. This damaged system makes it easy for theft, fraud, corruption, bribery, grafts, sabotage, espionage, and all kinds of illegal practices. At the same time, the change causes the used to be a professional public institution to become an amateur corporation that is individually managed, personally ruled, and undemocratic governance. Leadership does not exist in this system, neither does the middle level management, and it also suffers from severe democratic deficits and a badly divided government.

Using holistic and phenomenology approaches, this study reveals just as Rosen, Boothe, Dahlby, and Smith (1999) found in their study that the poor condition of the bureaucracy management system today is the result of the reinventing the government movement. Similarly, using the same approach, this paper proposes a remedial management system, a system that incorporate the contribution of the knowledge or mental workers and to emphasize the importance of applying theory to practice. Though many have been addicted to 
practicality, argued Chairman Mao in his Selected Writings, applying theory to practice is good for all works. It is a good habit. It produces higher standard and higher quality work, gives good foundation, promotes professionalism, and the result is more sustainable. Most importantly, it makes the tasks meaningful and endorses the understanding that the true purpose of education is, as White (1999) put it, to serve fellow citizens. The participants in this study are the Canadian elected officials and public servants, with the purpose is to study on the causes of bureaucratic dysfunctionality in terms of administrative management procedure in the Canadian government and propose a remedial system of management that is in line with the theory of bureaucracy and its application.

From the field of public administration, the first process to remedy the dysfunctionality of the bureaucratic organization is by understanding the theory of bureaucracy and applying its meaning to its management system.

\section{Theory of Bureaucracy}

Theoretically, bureaucracy is a formal organization (Merton, 1957; Riggs, 1994) that encompasses the entire unit of government - from the village government to municipal, county, provincial or state, and to the federal government or national government, including all their bodies, as well as the military units (the army, the police force, the air force, the marine, and the navy). It is a difficult, vast and complex organization (Jones, 2003; Blau \& Scott, 2003), a social administrator (Fu-Lay, 2008), and science and art (Frederickson, 2000). Olsen (2006/2005), Dube (1963), and Weber (1947) defined it as a hierarchical institution, one that, according to Meier and O'Toole (2006) "can provide the capacity and expertise to handle technically complex policy issues" (p. 1).

As a formal organization, the bureaucracy is not competitive, either between the different levels of governments or among bureaucratic organizations (Blau \& Scott, 2003; Graham, 2007; Kong, 2008; Svara, 2006), but driven by mission with multiple objectives (Graham, 2007; Thompson, 1967). It has certain administrative units and formally specializes in managing and organizing the flow of communication in each organization. Hamel and Breen (2007) stated that this certain administrative unit is formally specializes in managing, planning, organizing, and coordinating the flow of communication and personnel activities within the bureaucratic structure.

Bureaucracy is a unique organization (Kramer, 1998) - one that exists to accomplish production related to economic goals, organizes production through systematic and scientific inquiry, maximizes production through specialization and division of labor, knowledge, and expertise (Weber, 1947) and people act according to rational economic principles. It is an academic field (Selden, 1997; Ronquillo, 2008), a specialized scientific field application (Styhre, 2007), a field of professionalism and managerialism applications (Milakovich\& Gordon, 2008; Du Gay, 2005. It represents a machine model (McTigue, 2004), in which one engine mobilizes the works and activities of the other engines, anti-nepotism, anti-emotions or against individuality and cruelty, capricious and uses subjective judgments (Bennis, 1968). Its engines are part of a difficult, unique and complex organization (Jones, 2003; Kramer, 1998). 
As an organization, Frederickson (2000) also stated, the bureaucracy has forms, designs, experiences, language that, at its very best, is unique, compelling, and beautiful, has very high ideas and noble purpose of the society, while hierarchical structure is its norm. It is a mission driven organization (Graham, 2007; Shafritz\& Russell, 2000). Transforming the government into small business units, as McTigue suggested has resulted in the government loss its status as a public institution and with the emphasis on smaller government and the laying off public servants, the remaining public servants have neglected the raison d'ètre of the institution and public characteristics. The institution has lost its identity as a field with unique discipline, but merely small business units, whose bureaucrats are plutocrats (McTigue, 2004).

According to Weber (1947) and Olsen (2006), the bureaucracy is a hierarchical institution whose main responsibilities are to improve the welfare of the people in the state, maintain the sovereignty, protect the citizens, and maintain the economic political and social security stability of the country. It is a mission driven organization (Graham, 2007; Shafritz\& Russell, 2000). It is designed to emphasize different values (Kramer, 1998; Lowery, 2000), large and complex because it associates with the increasing complexities of social problems, the growth of human populations and its needs, and the fragmentation of the institution (Weber, 1947) with a formal structure and distinct characteristics (Aluko\&Adesopo, 2004). As a hierarchical institution, it "can provide the capacity and expertise to handle technically complex policy issues" (Meier \& O'Toole, 2006, p. 1), and promotes equality and impartiality in terms of gender, race, ethnicity, religion, and so forth (Selden, 1997). It is also a diverse and dynamic institution that utilizes knowledge and education expertise in conducting its daily tasks (Du Gay, 2000).

Added Weber (1947), the bureaucracy has the legitimate right to exercise control regardless of any resistance from the others and its administrative process is based on knowledge, scientific principles and managerial professionalism, which is in accordance with the theoretical foundation of public administration. Both Weber and Dube (1963) indicated that the bureaucracy exercises political power according to its nature of legitimacy in which it has several specific authorities, such as, charismatic authority based on individual's outstanding characteristics; traditional authority, which is essentially a respect for culture and custom; and rational legal authority, which is based on a code or a set of rules. It carries several goals, which are representativeness, transparency, equity or equal opportunity, equal access to services that the market cannot provide. The representation indicates that they represent the institution and use their knowledge and education to solve the problems or serve their fellow citizens, as White stated in her Education. These goals contrary to the individualistic goal of each bureaucratic organization or the common theme of goals that mimic that of the private corporation, which is efficiency (Radman-Liw\& Connaughton, 2005), doing more with less resources (Shim \& Siegel, 1997) or higher profits (Ross \& De Bettignies, 2004).

In terms of the administrative process, bureaucracy is a formal administrative structure with distinct characteristics and problems (Aluko\&Adesopo, 2004); it utilizes administrative, scientific modes of thinking with scientific procedures and practices (Styhre, 2007), and it is fiduciary of the people (Long, 1952). As a hierarchical institution, it is "designed rationally to 
coordinate the work of many individuals in the pursuit of large scale administrative tasks" (Aluko\&Adesopo, 2004, p. 15), and to solve public problems (Harari, 2003). Scientific work cannot be done in a fast phase mode or applying theory into practice needs time, not speed.

Weber (1947) argued that bureaucracy has a hierarchical structure and it is the most efficient and effective organization. It is congruent with the Constitution because it has a "moral obligation to preserve and sustain constitutional principles" (Rohr, 1986, p. 181) and it is autonomous, but no one is overlapping the other in terms of jurisdiction, duties, responsibilities, and authorities. This structure gives the leaders an active role in managing the administration of the bureaucracy, not as performing actors.

Elliot Jacques (1990) agreed with Weber that it is the most efficient, the hardiest, and the most natural structure ever devised for a large and complex organization. It is not rigid, insensitive or power striving, but a feature of modern organizations whose character is greater effectiveness (Aluko\&Adesopo, 2004). With its hierarchical structure, the bureaucracy reveals its democratic characteristics (Dube (1963). This hierarchical structure eliminates personality and non-rational decision (Merton, 1957) and bureaucratic personnel are required to perform their tasks with managerial professionalism and to provide impartial treatment to the citizens (Aluko\&Adesopo, 2004), which determines the success of the organization and that of the society (Boyte, 2004) as a whole. It also promotes equality and impartiality in terms of gender, race, ethnicity, religion, and so forth (Selden, 1997).

From the Weber's work, Von Mises (1983) argued that this hierarchical structure ensures that everyone shares the responsibility to relieve social and economic burden of the society. It emphasizes the word of Abraham Lincoln or Thomas Jefferson that the government is of the people, by the people and for the people (Boyte, 2004). This is related to what is defined in the Constitution that a person's power is limited to his authority and responsibility. Without this limitation, there is a tendency for a man in power to become an autocrat, a totalitarian, or a dictator, especially those whose main goal to enter the bureaucracy is to satisfy their ego (Docherty, 1990) or to have access to public resources (Lebovic, 2006).

Blau and Scott (2003), Graham (2007), Kong (2008), and Svara (2006) argued that as a formal organization, the bureaucracy is not competitive, either between the different levels of governments or among bureaucratic organizations but, it is driven by mission with multiple objectives (Graham, 2007; Thompson, 1967). It has certain administrative units and formally specializes in managing and organizing the flow of communication in each organization and this certain administrative unit is formally specializes in managing, planning, organizing, and coordinating the flow of communication and personnel activities within the bureaucratic structure (Hamel \& Breen, 2007).

The bureaucracy represents the public and to produce and manage it according to public preferences (Meier \& Krause, 2003) to serve the public (Dube, 1963). It is also a human agency or what Levy (1971) called as a "human relations" agency that requires intellectual capacity, the higher is the level of the bureaucracy, the higher is the intellectual requirements as Tiebout (1956) mentioned that it is the tool for the government to use to design economic development. The activities in the government are conducted not according to profit or loss 
statements. The achievement of the bureaucracy cannot be expressed in terms of money, but in terms of the mission achieved. While many are trying to remove the bureaucracy and replace it with a corporation, Kaufman (1976) stated once the bureaucracy is established, it is difficult and impossible to eliminate it because, agreed Rosen, Boothe, Dahlby, and Smith (1999), it has roles and functions that the market cannot fulfilled.

Consistent with this theory, Rosenbloom and Rene stated that bureaucracy is an executive and managerial field. This includes legislative functions of rulemaking and adjudication, which are the functions of the government as legislative or substantive, procedural and interpretive, transparency and individual rights, and how judicial trial is a process, not a political endeavor, and it has some flexibility and focuses on legal rights and obligations, not on the administrative cost-benefits analysis.

According to Kaplan (1968), bureaucracy is an organization that is designed for social development with theoretically oriented, to provide latent structures to meet the changing contingencies of the development process, to work with the entire social system, to perform socialization or re-socialization functions, and is committed to emphasize its practice on norms, standards, and values of the society. Weber (1947), Meier and Krause (1997), as well as Rosen, Boothe, Dahlby, and Smith (1999) explained that bureaucracy has legitimate power and specific authorities. These authorities make the members of the bureaucracy to obey the rules or codes of the organization (Dube, 1963). The law of the bureaucracy indicates that it looks after the interests of the people. Officials in the bureaucracy, even though they have these authorities, obey these authorities within the limit of the law (Dube, 1963).

\section{Methodology}

Real problems require real solutions. Using this qualitative approach, holistic and phenomenology approaches, I can derive the study from the existing problem. This method is more effective because I can find a deeper truth (Greenhalgh\& Taylor, 1997; Genzuk, 2009) about the problems, study the phenomenon in their natural setting, and attempt to make sense of or interpret the lived experience of the phenomenon, the meaning they bring into this study as suggested by Greenhalgh and Taylor (1997) or Genzuk (2009. I can use holistic perspective to preserve the complexities of human behavior as suggested by Greenhalgh and Taylor (1997) or Genzuk (2009) because humanity is one of the principles of the bureaucracy (Fischer \&Sirianni, 1984/1994). This approach also enables me to see the organization as a whole unit not only a piece of it.

By using qualitative method, I am also able to describe the phenomenon "in a more humanistic and phenomenological view" (Higgins, 2009, p. 25) to preserve the principles of the bureaucracy. In addition, the bureaucracy is a qualitative field (Meier \& O'Toole, 2003) and a subjective field.

\section{Findings}

Leadership does not exist or that the leaders are "lost" or "just simply lost" and without job descriptions. They spend $60 \%$ of their time outside the organizations, but some leaders hold several leadership portfolios at one time. They come to work in the bureaucracy on an ad hoc 
basis (Chubb \& Peterson, 1989). Leaders never read the incoming and outgoing information, all are processed at the bottom level by the frontline staffs or the political exempt staffs. Since there is no oversight by the leaders, personnel forge leaders' signature to induce bribery and corruption, thefts, collusion, and theft of citizens' identity, while the leaders are irresponsibility and non-accountable leaders and personnel. Public information are not guaranteed safety. Personnel steal public's personal information and use the system to scam the citizens. Personnel consider public problems are a nuisance. It is a hollow system of management. There is absence of knowledge and knowledge experts, which are becoming an endangered species and the system is becoming labor oriented, poor standard and quality of goods and services because the system is run based or according to self-managed team whose members are combination of public servants, temporary staffs or borrowed personnel from the staffing agencies, contract staffs, volunteers, and each operates according to his own interpretation. Leaders and personnel are ignorant and the administrative system is treated as personal matter or that personality override professionalism.

In this system, every person can become a leader as soon as after political election or after the cabinet shuffle, while for line function managers or the career public servants, their positions represent a dead end career or no career advancement because the three top leadership positions have been designated to political appointees who come directly from the outside through the political parties. Hiring and promotion are based on political considerations. In terms of education, leaders and personnel are poorly educated or lack education (IPAC, 2011), while knowledge intellectuals represent an endangered species in the government (Styhre, 2007). The leaders and personnel do things orally. Political leaders and the political exempt staffs speak in acronyms that only them understand.

With the leaders are without job descriptions and come to work in the public office on an ad hoc basis (Chubb \& Peterson, 1989), turnover rate among high echelon leaders is very high. When the leaders leave the bureaucracy, their political exempt staffs also leave with them. It creates another high turnover rate among the political exempt staffs as well. It causes constant reorganization, constant change in the management and the administrative system, and the government becomes very unstable in all its aspects - from the leaders to the subordinates, to the management and administrative system. In addition, there is also a constant conflict among the political appointees and the political exempt staffs and the public servants, and the main cause of conflict is personality, tacit knowledge versus, explicit knowledge and feelings versus professionalism. Education becomes insignificant while tacit knowledge is prioritized. Leaders under this dual system are pursuing their own interests and spend most of their time on the negotiating table, negotiating trade deals between the government and the stakeholders and to distribute public resources upward (Boyte, 2004) at the expense of the poor and the middle class (Covell, 2004; Dobson, 2006). The Canadians' standard of living and their quality of life are declining, the quality of public goods and services are also declining. The Canadians began to feel that they are heading toward the condition of the developing countries.

The management system becomes a combination of personal and unprofessional, which is handled by the frontline staffs who come into the organization with the elected and appointed 
leaders and the original bureaucratic system, managed by the public servants. Constant conflict in the administrative management between the public servants and the exempt political staffs, but most is due to personality or "ego" and constant sabotage. Political exempt staffs take control of the incoming information, sabotage them, and protect the regime from public embarrassment due to scandals. As the bureaucracy is politically managed, all the administration is controlled by the political exempt staffs and they treat the incoming and outgoing information as personal business, so is in its filing system. Just as the politicians mix business, politics, and pleasure (Ferry, 2008), the political exempt staffs also mix politics, business and personality and they contribute to the organization dysfunctionality and the broken system. The system becomes more personal rather than professional and managed in an amateur manner. In addition, public inputs cost millions annually in the forms of travel, accommodation, meal and entertainment of the politicians and politically appointed leaders. Forgery, which is a crime, has become a culture in the bureaucracy. Trust is lacking within the system and the politicians treat each other as adversaries.

Visually, the current system is or has been designed, as stated in the findings, to consist of the following, without knowledge or mental workers or as a hollow system:

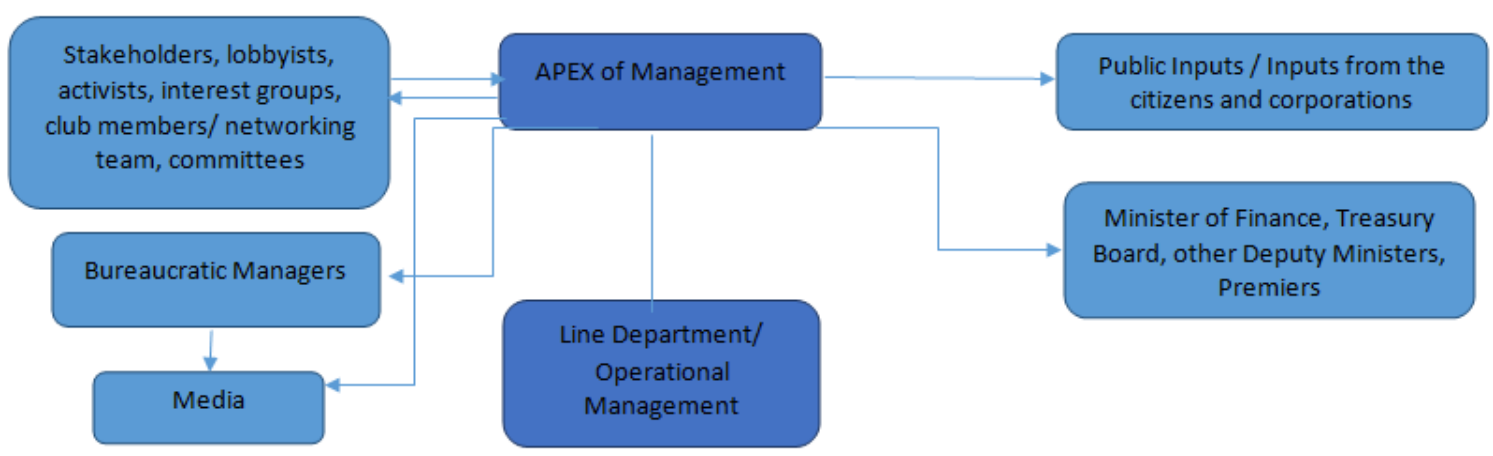

This diagram reveals that each level of management pursues its own interests and does its own things without leadership roles, or as stated, leadership does not exist. The leaders spend $60 \%$ of their time having meetings with the stakeholders, lobbyists, activists, and interest groups, attend committee meetings, networking, fundraising activities, and seek public inputs. The other $40 \%$ of their time are used between their own business and public office. The leaders read none of the incoming and outgoing information because, they, which is similar to Killian's (2005/2007) findings, pursue their own team and networking at the top. Both the elected and appointed leaders do not have job descriptions (Anderson, Hilderman, \& Loat, 2010). Rather, according to CISCO Corporation's director of development, every day, the elected and appointed leaders go to their company seeking ideas. The leaders have little knowledge about the organization they lead, talk big, but do very little (Clawson, 2003). They come to the public office on an ad hoc basis (Chubb \& Peterson, 1989).It also reveals the absence of knowledge or mental workers, which according to Chairman Mao, are the key to a successful bureaucracy.

The line department or the operational management consists of a combination of public 
servants, political exempt staffs, volunteers, contract and borrowed personnel from the staffing agencies, contractors and/or consultants. In addition, these frontline staffs also consists of the citizens, immigrants, permanent residents and non-permanent residents, and foreign workers who come to Canada under working permits. They all do the same work, without training, share the same office space, and use the same facilities. They all are people with the same knowledge and experience, and have the same backgroundand are pooled together to perform multiple tasks (McShane, 1992). In fact, in this system of management, education and knowledge expertise are considered insignificant, but as in Taylorism, experience and practicality or tacit knowledge are considered as assets to the organization. The security of the system is no longer valid. Without knowledge and training, things are processed at the line department by the frontline staffs according to their own interpretation how things should be done. Consequently, serving the citizens becomes a personal matter while solving public problems is a nuisance to the frontline staffs (Ciotti, 2013).

Conflict between the public servants and the political exempt staffs is a perennial problem, but the main reason of the conflict is personality (Anderson, Hilderman, \& Loat, 2011). Besides this conflict, public servants suffer from poor morale and the environment becomes toxic due to the "spontaneous remarks" cast by the elected and appointed leaders as well as the political exempt staffs toward the public servants. The "spontaneous remarks" involves negative put down, sarcasm, and rudeness, while those at the line management positions are suffering from mental and psychological disorder (IPAC, 2011). The average terms of service among the appointed and elected leaders is between six months and twenty-four months. When the leaders leave, their political exempt staffs also leave with them. With the constant change in leadership and the political exempt staffs, there are also constant reorganization in the human resources, the system of management becomes very dysfunctional, the government becomes very vulnerable, and the administrative system is broken. The filing system is mingle of personal and professional and things become more personal than professional. When the people leave the office, information and evidence were shredded. Responsibility and accountability do not exist in this new management system.

The Effective Administrative Management System of a Public Organization

The propose study is presented in the following diagram:

- In this diagram, it requires that the leaders must read and listen, which are the first job descriptions of the leaders. It helps the leaders to obtain the up-to-date information and

- improves their analytical skills and critical thinking skills, helps them in their daily tasks that involve planning or designing, managing, delegating, organizing, coordinating, and controlling, which in turns, improvers their ability to make decisions professionally.

- improves their vocabulary building that they become broad minded and wise in their words and expressions, teach them to care and have passion and compassion for the citizens. 


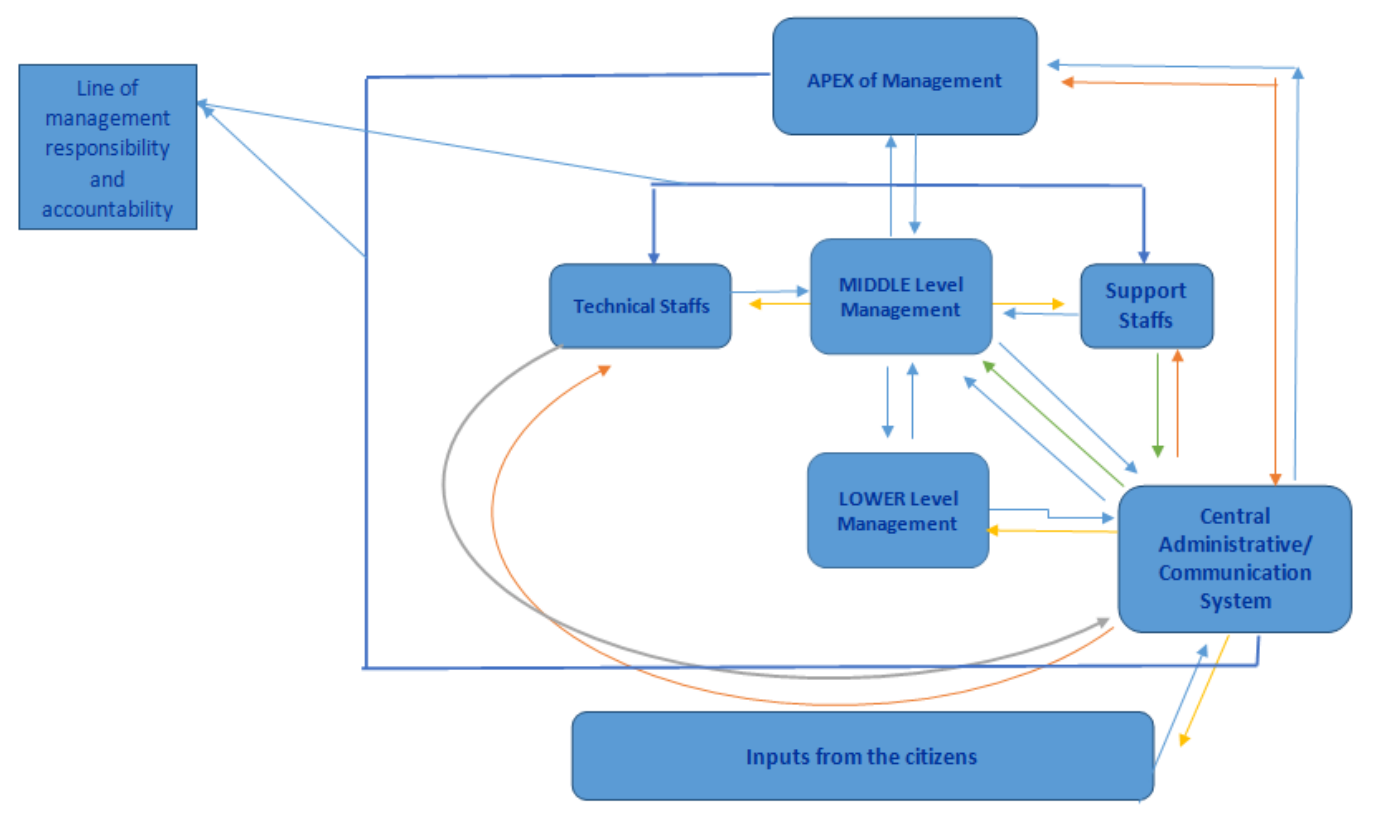

- helps them to love and have sympathy toward the people, to become patience and perseverance and committed in their duties as leaders

- helps them to develop their leadership skills

- removes nepotism and enforces professionalism where people work in the government based on their intellectual ability, which is filtered through a comprehensive exam as Brookes (2008) stated that their level of education, professional trainings and experience, as well as their technical capacity should be tested comprehensively. Add, agreed Simon, Thompson, and Smithburg (2000), they must pass a minimum standard. It reinforces respect toward education, knowledge and knowledge expertise, authority and responsibility.

- reinforces developmental process that involves leadership, personality traits, leadership skills, improves efficiency and guarantees a democratic system. Anthony (2007) called this system, as he associated to leadership, "dying like a seed." It reinforces what is stated in the theory of bureaucracy, a dynamic process.

- enforces that leaders are doers not performers who come to the public office one an ad hoc basis (Chubb \& Peterson, 1989) to get together, but a full time public employee. The true meaning of public leadership is that the leaders are employees of the public. Abraham Lincoln said they are the servants of the public. This is 
visible in this management of the administrative system.

- makes the tasks and leadership to be more meaningfulbecause working in the government is to serve fellow citizens. Both the leaders and subordinates use their knowledge expertise or apply theory in practice to serve the citizens, which, according to Chairman Mao, good for all works and it makes the task meaningful. This also emphasizes and reinforces what White stated in her Education that the true purpose of education is to serve our fellow citizens. And to serve the citizens, it requires the government that operates not as a "one man band," but one that is established "of the people, by the people and for the people."

- This system requires active leadership roles and involvement in every level. They are masters of the tasks, educators, and they perform leadership functions according to their knowledge specialization, and the specialization of the organization. In other word, if the New Public Management creates all organizations to be equal in tasks or duplicates each other's roles and responsibilities, this diagram emphasizes not only on the use of knowledge specialization but also on the organization specialty. Each organization has its specialization and there is no duplication of duties and responsibilities.

- This diagram shows that a person should go through a development process, must take a comprehensive exam and pass a minimum standard (Brookes, 2008; Simon, Thompson, \& Smithburg, 2000)) before he is assigned to a higher echelon position.

- This diagram shows that working in the government requires a comprehensive use of education and multidiscipline knowledge expertise. Tacit knowledge and practicality have no place in an academic and scientific fields, and a field of managerial and professionalism.

- It reduces the cost of public consultation to zero and promotes equal access for the citizens. It ensures that the leaders work or serve the citizens without looking at their economic level, social background, and ethnic or racial background. It allows the leaders to do work as doers of the task rather than being performing actors. It allows them to develop their capacity and build the capacity of their subordinates at the same time.

- This diagram also shows that working in the bureaucracy requires leaders who have education, knowledge expertise, technical capacity, and possess all qualities, including personality traits.

- Making decision professionally indicates that the leaders use scientific realities, factual evidence, and ethical considerations which also involve putting the public first above self-interests $\rightarrow$ which involves the use of education, knowledge and knowledge expertise. In order to place public first and self-last, it requires that the leaders must go through a transformational process. It is impossible to assign a person 
to a leadership portfolio as soon as after political election or after the cabinet shuffle. This practice causes high turnover rate among public leaders.

As professional organizations, it emphasizes thatno one will be appointed to a leadership position without going through a development process. The person must go through a comprehensive exam (Brookes, 2008) to a certain leadership position without knowledge expertise and experience in that particular field. Then the person should also go through a special training to familiarize himself with the tasks so that he will become master of the task. This process leads to a personality trait development. If leadership is developed over time through formal and informal education and professional training and experience, so do the leaders' personality traits. This process leads to a higher technical capacity. A good and democratic leader is a person with high technical capacity. It is impossible for a person to become a public leader over night or as soon as after political election. This process is the same as putting an innocent child in the middle of a traffic light and let him choose which way to go. In no time, he will be dead and if he is not dead, he creates a crisis and causes a dysfunction organization. As a person goes up through a hierarchical leadership position, the more complex the problems and wider are the scopes of the problems. Therefore, the leaders must be prepared to face with these realities and that they should know how to handle all the complex problems, not as a one man band, but a person who considers the importance of knowledge and knowledge specialization.

Having the central administrative system removes all the personality or all that sounds personal relationship. This is in accordance with the theory of bureaucracy, which is anti-nepotism. As this system emphasizes on the use of education and knowledge expertise, the person in charge of the central administrative or communication system should be a person with the highest knowledge possible. He is a person who respects education and knowledge, has the comprehensive knowledge about the organizational structure vertically and horizontally, not only within the organization he is working, but also all through the bureaucratic organizations circle. He knows well the responsibilities, duties, and functions of the different organizations and the specialty of each bureaucratic organization.

This system of administration requires high leadership involvement in every task - one who masters the task and can take charge of the task. Different from the New Public Management system where the leaders are "mentors" or "coaches," or to the Canadian Deputy Ministers, they call "internal buddies," this administrative system requires the leaders as leaders. "Mentors," "coaches," or "buddies" are not required to know the tasks, but are people who are simply there to answer questions when the subordinates are in doubt.

Leaders of this effective administrative and management system, on the contrary, are required to be "masters of the tasks" and "educators." They must master the tasks first, then, they educate their subordinates how to do the task. When the subordinates make mistakes, they will correct it. And in order to correct the mistake, they must read the completed task done by their staff. Hence, the system requires that information that comes in and goes out must go through the leaders' desk at every division. It is not a "one man band" as in the New Public Management system, but it reinforces the principles of, as stated by Abraham Lincoln, 
"Government is of the people, by the people, and for the people." The communication that comes in and go out must go through the different desks of leaders who have knowledge expertise, who then, will assign their staffs to support them with the duty. The leaders, who have the knowledge expertise, will review the work of their subordinates, provide feedback for correction, and forward the information to the central administrative unit to be distributed to the higher level and finally to the top level of management for approval. This process requires longer time processing because, every task done in the bureaucratic organization requires the use of scientific realities. It requires mental work or intellectual digestion.

\section{Conclusion}

The bureaucracy is a formal, vast, difficult, complex, and unique organization. It is an academic and scientific field, a field of managerial and professional application, anti-nepotism, and it is hierarchical in design to incorporate the widely and comprehensive use of education, knowledge and knowledge expertise in leadership, overall management, and its administrative system. It is established to serve the citizens regardless of their economic status, social and ethnic or racial background.

The use of education, knowledge, knowledge expertise, and professionalism in this management system is to enforce professionalism, improve efficiency, guarantee a democratic system, develop the skills and capacity of the leaders and personnel, and enforces the principle of the government is "of the people, by the people, and for the people."

\section{References}

Aluko, A. A. O. \&Adesopo, A. A. (2004). An appraisal of the two faces of bureaucracy in relation to the Nigerian society. Journal of Social Science, 8 (1), 13-21.

Alvinus, A. (2012, autumn). The Inadequacy of Bureaucratic Organizations: Organizational Adaptation through boundary spanning in a Civil-Military Context. Res Militaries, 3 (1).

Blau, P. M. \& Scott, R. W. (1962). Formal Organizations: A comparative approach. San Francisco, CA: Chandler Publishing Co.

Bourgault, J. (2005). Corporate Management Practices in Government of Canada: A fact finding report and networking initiative. Ottawa, ON: Canada School of Public Service

Brookes, S. (2008). The Public Leadership Challenge: Full Research Report ESRC Seminar Series End of Award Report, RES-451-25-4273, Swindon ESRC. Retrieved August 14, 2008 from http://www.publicleadership.org/word/esrc-final-summary-july_08.doc.

Chubb, J. E. \& Peterson, P. E. (Eds.) (1989). Can the Government Govern? Washington, DC: The Brooking Institute.

Ciotti, G. (2013, February 20). Fifteen customer service skills that every employee needs. Hep Scout.

Covell, C. (2014). Human Resources Management in the Public Sector and the Roles of the 
Intellectuals in the Management of the Administrative State. A Paper prepared for the Presentation at 2014 International Symposium on Ethical Leadership (ISEL 2nd) "Building Good Governance/Combating Corruption," October 26 - 27, 2012, UESTC, Chengdu, P.R. China.

Covell, C. (2015). Public Management of the $21^{\text {st }}$ Century - Second Series: The Canadian Association for Programs in Public Administration Conference, Toronto, Ontario - Research Conference in Public Management, June 2015.

Downs, A. (1967). Inside Bureaucracy. The Journal of Politics, 30 (3), 292.

Du Gay, P. (2005). The Values of Bureaucracy. London, England: Oxford University Press.

Dube, S. C. (1963, March 5). Bureaucracy and Nations Building in Transition Societies. United Nations Educational Scientific and Cultural Organization. Expert Working Group on Social Prerequisites to Economic Growth. Kyrenia, Cyprus, 17-26 April 1963.

Engstorm, T. E. (1979). The Making of Christian Leader: How to Develop Management and Human Relations Skills. Grand Rapids, MI: Zondervan Publishing House.

Fischer, F. \&Sirianni, C. (1984/1994). Critical studies in organization and bureaucracy. Philadelphia, PN: Temple University Press.

Frederickson, H. G. (1999). Ethics and the New Managerialism. Public Administration \& Management: An Interactive Journal, 4 (2), 299-324. Retrieved June 30, 2010 from EBSCO Academic Premier.

Fu-Lay, T. Y. (2008, August). Uncertainty human agency and e-government. Transforming Government People, Process and Policy, 2 (4), 283-296.

Genzuk, M. PhD. (2009, fall). Qualitative Research: An Introduction to Reading and Appraising Qualitative Research in Education. Center for Multilingual, Multicultural Research Rossier School of Education, University of California.

Greenhalgh, T. \& Taylor, R. (1997, September). How to read a paper: papers that go beyond numbers (qualitative research). BMJ, 315 (7110), 740.

Ghoshal, S. (2005). Bad Management Theory Are Destroying Good Management Practices. Journal of Academy of management Learning and Education,4 (1), 75-91.

Ghosh, S. (2012, December 13). When the mind is without fear and mouth is without fear. Open India News Online.

IPAC (2011, December 33). Working with Political Staff.

Kaplan, B. H. (1968, December). Notes on a non-Weberian Model of Bureaucracy: The Case of Development Bureaucracy. Administrative Science Quarterly, 13 (3), 471-483.

Kong, D. (2008). Performance Management or Score Management? New Challenges for Democratic Accountability. The Berkley Electronic Press, 4 (3). 
Koonings, K. \&Kruijit, D. (2002). Political armies: the military and nation building in the age of democracy. London, UK: Zed Books.

Kramer, R. (1998). Nonprofit Organization: Will Sector Matter? Policy Series. The Aspen Institute.

Lowery, D. (2000, March). The Presidency, the Bureaucracy, and Reinvention: A Gentle Plea for Chaos. Presidential Studies Quarterly, 30 (1), 79-108.

McTigue, R. M. Hon. (2004). Turning Bureaucrats into Plutocrats: Can Entrepreneurialism Work in the Federal Government? A Testimony for the Committee on Government Reform of United States House of Representatives. Retrieved August 24, 2005 from http://www.mercatus.org/pdf/materials/1275.pdf.

Meier, K. J., O'Toole Jr., L. J., \& Hawes, D. (2007). Testing the Theoretical Determinants of Political Control over theBureaucracy: Taking Wood and Waterman Seriously.Conference Papers - American Political Science Association, 2007 Annual Meeting, 1-40.

Meier, K. J. \& Krause, G. (2003). The Scientific Study of Bureaucracy: An Overview. Politics, policy, \& organizations: frontiers in the scientific study of bureaucracy. Ann Arbor, MI: Michigan University Press.

Merton, R. K. (1957). Bureaucratic Structure and Personality. Social Theory and Social Structure. Glencoe, IL: Free Press, 195-206.

Milakovich, M. E. \& Gordon, G. J. (2008). Public Administration in America.Cengage Learning.

Mintzberg, H. (1996, May/June). Managing government, governing management. Harvard Business Review, 75-83.

Olsen, J. P. (2005/2006, March). May be it is Time to Rediscover Bureaucracy. Journal of Public Administration and Theory 16 (1), 1-24.

Olson, E. E. \&Eoyang, G. H. (2003). Facilitating Organization Change: Lessons from Complexity Science. San Francisco, CA: Jossey-Bass Pfeiffer.

Radman-Liw, T. \& Connaughton, B. (2005). Public administration as a field of study: Divergence or Convergence in the light of Europeanization? Trames, 9 (59/54), 4, 348-360.

Rainey, Hal G. (1997). Understanding \& managing public organizations ( ${ }^{\text {nd }}$ Ed.) San Francisco: Jossey-Bass.

Riggs, F. W. (1994, January/February). Bureaucracy and the Constitution. Public Administration Review, 54 (1), 65-72.

Rotberg, R. I. (2006). The Roots of Africa's Leadership Deficit. Compass, Center for Public Leadership, 28-32.

Selden, S. C. (1997). The promise of representative bureaucracy: diversity and responsive in a government agency. New York, NY: M. E. Sharpe. 


\section{Macrothink}

Journal of Public Administration and Governance ISSN 2161-7104 2016, Vol. 6, No. 2

Shafritz, J. M. \& Russell, E. W. (2000). Introducing Public Administration. New York, NY: Addison Wesley - Longman.

Sifuna, D. (2000). Education for Democracy and Human Rights in African Schools: The Kenyan Experiences. Journal of Africa Development, xxxv (1 and 2), 213-239.

Sir Mc.Tigue, M. (2005). Turning Bureaucrats into Plutocrats: Can Entrepreneurialism Work in the Federal Government? A Testimony for the Committee on Government Reform of United States House of Representatives. Retrieved August 24, 2005 from http://www.mercatus.org/pdf/materials/1275.pdf

Svara, J. H. (2007). The Ethics Primer for Public Administrators in Government and Nonprofit Organizations. Tempe, Arizona: Arizona State University Press.

Styhre, A. (2007). The Innovative Bureaucracy in an Age of Fluidity. New York, NY: Francis \& Taylor.

Thompson, J. R. (2005). Organization Theory and Public Management. Australia: Wadsworth.

Von Mises, L. (1944). Bureaucracy. New Haven, CT: Yale University Press.

Weber, M. (1947). The Theory of Social and Economic Organization. Translated by A. M. Henderson \& Talcott Parsons, The Free Press.

Welch,E. W.\& Pandey, S. K. (2007). E-Government and Bureaucracy: Toward a Better Understanding of Intranet Implementation and Its Effect on Red Tape. Journal of Public Administration Research Theory, 17 (3), 379-404.

Von Mises, L. (1983). Bureaucracy. Grove City, Penn: Libertarian Press.

White, E. G. (1979). This Day with God. Ellen White Estate Inc. Hagerstown, MD: Review and Herald Publishing Association.

White, E. (1952). Education. Boise, Idaho: Pacific Press Publishing Association

\section{Copyright Disclaimer}

Copyright for this article is retained by the author(s), with first publication rights granted to the journal.

This is an open-access article distributed under the terms and conditions of the Creative Commons Attribution license (http://creativecommons.org/licenses/by/3.0/). 